\title{
"THOUGH MUCH IS TAKEN" -- REFLECTIONS ON AGING, HEALTH, AND MEDICAL CARE
}

\author{
Victor R. Fuchs
}

Working Paper No. 1269

\author{
NATIONAL BUREAU OF ECONOMIC RESEARCH \\ 1050 Massachusetts Avenue \\ Cambridge, MA 02138 \\ January 1984
}

Please do not quote or reproduce this paper without author's permission. Prepared in connection with a conference on future of Medicare, November 29-30, 1983, in Washington, D.C. I am grateful to the Robert Wood Johnson Foundation for their support of the NBER's research program in Health Economics, and to Leslie Perreault for research assistance. The research reported here is part of the NBER's research program in Health Economics. Any opinions expressed are those of the author and not those of the National Bureau of Economic Research. 


\section{"THOGG MUCH IS TAKEN"--REFLECTI ONS ON AG NG,}

FEALTH AND MED CAL CARE

\section{Abstract}

The Medicare trust funds face huge prospective deficits by the end of this decade. This paper discusses trends in six areas that bear on the Medi care problem the number of the elderly, thei $r$ heal th status, use of nedi cal care, I abor force partici pation, i ncone, and I i ving arrangenents. Anong the nost inportant findings are: 1) a very I arge increase si nce 1965 in Iife expectancy at age 65; 2) a very Iarge increase since 1976 in real per capita health care expenditures on the elderly relative to expenditures on persons under age 65; 3) a cross-secti onal increase with age in per capita heal th care expenditures that is primarily attributable to very Iarge expendi tures in the Iast year of life; 4) a sharp decrease in Iabor force participation and a sharp increase in relative incone of the elderly since 1965. The paper concl udes by rai sing questions about the need to reconsider the definition of the elderly, the need for nore flexible I abor market arrangenents for ol der uorkers, and a need for a social consensus concerning appropriate care of dying patients.

Victor $\mathbf{R}$ Fuchs Nati onal Bureau of Economic Research 204 Junipero Serra Boul evard Stanf ord, CA 94305 
"THOUG MaH IS TAKEN"--REFLECTIONS ON AG NG FELTH AND MEDCAL CARE

\author{
Victor $\mathbf{R}$ Fuchs \\ Stanf ord Uni versity \\ and \\ Nati onal Bureau of Economic Research
}

"Though much is taken, much abi des."

--Al fred Lord Tennyson

Less than one score years ago this nation brought forth a new system of fi nanci ng heal th care for the el derl y-- Medi care. Thi s system concei ved as part of a broad thrust toward a "Great Soci ety" and dedicated to the proposition that high quality nedical care should be freely available to al I persons 65 and over, is now the subject of intense re-exani nation. The rapid rate of grouth of heal th care expenditures, the growing resi stance to further increases in governnental taxes or deficits, and the changing circunstances of the elderly make this an appropriate tine to ask (and attempt to answer) basic questions about the econonic and social forces that affect this age group and this program

Projections of Medicare outlays and revenues indicate very I arge future deficits in the Hospital Insurance trust fund and the Supplenentary Medi cal Insurance trust fund. A wide range of possible sol utions to this probl em have been proposed, incl uding nodification of benefits, changes in nethods of rei nbursenent, and di scovery of new sources of funds. The other papers in this vol une examine these proposals in detail. This paper attenpts to place the Medicare issue in a broad context by identifying mjor econonic and social trends that concern the elderly and by briefly considering the causes and consequences of these trends. I do not di scuss Medi care di rectl y, 
but the questions. raised and the data presented will, I hope, contribute to the formul ation of i mproved publ ic policies regarding health care for the el derly.

I begin by supposing that a policy maker with a strong interest in the el derl y had di sappeared i $\mathbf{n} 1950$ and had onl y recent l y ret urned. What nould he or she nost need to know about the el derly with respect to thei $r$ current si tuati on and the changes of recent decades? I $\mathrm{n}$ my judgnent there are si $x$ areas that are of critical i mportance: the nunber of el derly, thei $r$ heal th status, use of medical care, I abor force participation, i ncone, and thei $r$ living arrangenents. I di scuss the nost dranatic changes in these areas during the past three decades, indicate how current policies may have contributed to these changes, and suggest the need for reconsideration of those policies.

The Number of El derly

Al nost every article and book about the el derly begins by noting that the percentage of the popul ation over 65 has grown appreci ably over ti ne. Why is there so nuch interest in this percentage? Fi rst, it is assuned that nost nen and wonen aged 65 and over are not at uork; therefore, part of the uorking generation's output must be transferred to the elderly through social security paynents, pri vate pensi on plans, di rect provi si on of services, or other neans. The higher the percentage of elderly, the greater the anount that must be transferred. Second, it is assuned that heal th deteri orates with age and that the consumption of nedical care increases. Furthernore, it is argued that even though the decline in I abor incone, the deterioration in heal th, and the i ncreased use 
of nedi cal care are, for the nost part, foreseeable, many el derly cannot or do not adequately provide for old age by saving or by acqui ring

a health insurance policy when young that would protect them Iater in Iife. ( I mperfecti ons in insurance markets, problens of adverse sel ection, and high administrative and sal es costs are said to contribute to this outcone.) Finally, the rise in the number of elderly increases their political poner. Thi s increase, coning at a ti ne when economic resources are of ten allocated through the ball ot box rather than the market place, raises the possibility of bitter political conflict between the elderly and other groups in society. The definition of old age-that is, the age of eligibility for reti renent and Medicare benefits--is a critical variable in the devel opnent of viable prograns for the elderly. Consider, for instance, a hypothetical popul ation in which the bi rth rate equals the death rate and everyone dies at 80 years of age. If every man and woman works from ages 20 to 65 and then retires, the ratio of norkers to retirees will be three to one. If. hovever, the retirenent age is 70 , there will be five norkers for every retiree, thus pernitting a substantial increase in benefits or decrease in taxes, or both.

It is conventional to define the elderly with reference to the number of years si nce bi rth, but this is I argely a concessi on to admini strative conveni ence rather than the logical result of a closel y reasoned argunent. I ndi vi dual s "age" at very different rates and, in theory at least, the el derly could be defined in terns of years until death, e.g., those nen and wonen who will die within sone specified tine. For instance, we could look at the proportion of the population that will die within one year (the crude death rate). According to this measure the proportion has decreased si nce 1950. To be sure, it doesn't make much sense to define infants, children, and 
young adults as "el derly," even if they are cl ose to death. But a count of persons 65 and over who will die within the next several years is inf ornative because much of the interest in the elderly revol ves around thei $r$ need for nedi cal care and other speci al servi ces. Froma di fferent perspective, a count of persons 65 and over who are not in the Iabor force is revealing because it shows the portion of the population that must Iive on transfer paynents, incone from capi tal, or di ssavi ng.

These al ternative vieus of who is old yield different trends in the rel ati ve i mportance of the el derl $y$, as may be seen i $n$ Tabl e 1 . The first row shows the familiar increase in the proportion of the population 65 and over, from 8.2 percent in 1950 to 11.3 percent i $\mathbf{n} 1980$. The second row however, shows that if we define the el derly as persons 65 and over who will die within five years, this number as a percent of the total population has i ncreased rel ati vely sl owly si nce 1950 and has hardly grown at al si nce 1965. Sharp decli nes in age-specific death rates at ages 65 and above have offset the effect of the increase shown in the first row on the other hand, if we define the elderly as persons 65 and over who are out of the Iabor force (row 3). that proporti on has grown even nore rapi dly than the percent over 65 . 
Table 1. The "el derly" as a proportion of the total population: al ternative defi ni ti ons.

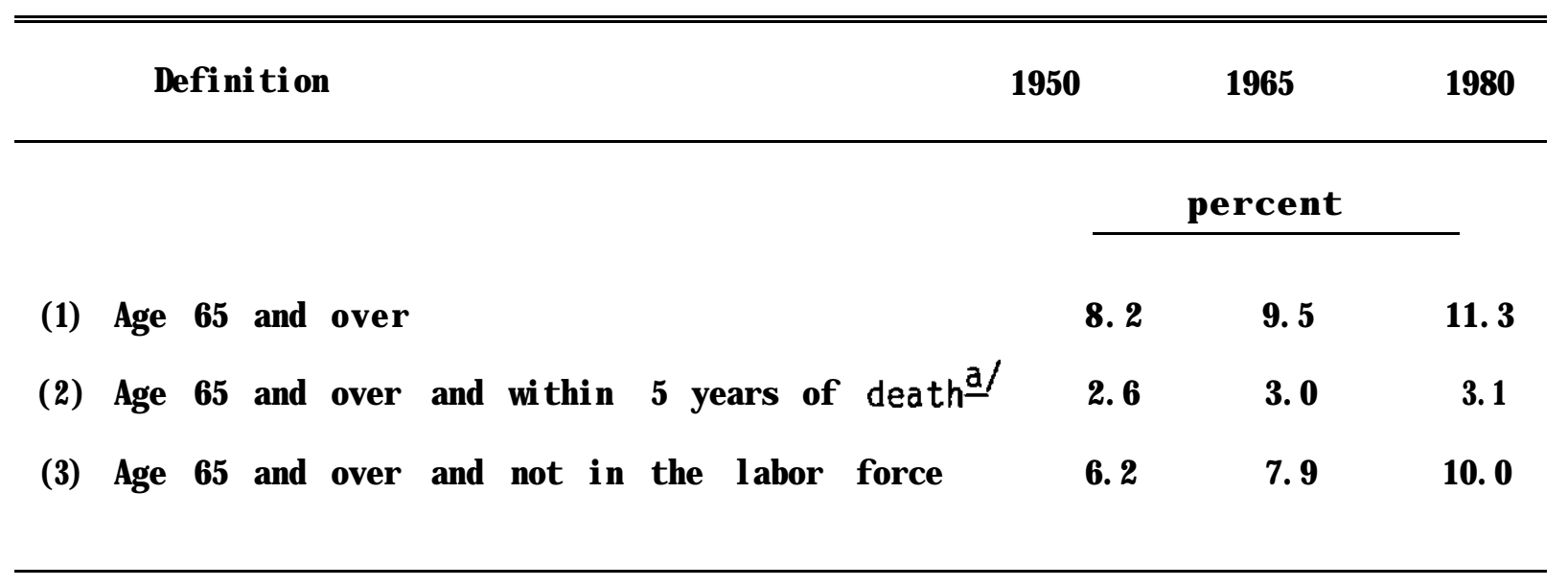

a/ Estimated by author.

Sources: U.S. Bureau of the Census, CurrentPopul ation Reports, Seri es P- 25, Nb. 310, Table 1 (J une 30, 1965); Nb. 519, Table 2 (April 1974); Nb. 917, Table 2 (J ul y 1982).

U.S. Bureau of the Census, Historical Statistics of the United States, Col oni al Ti nes to $1 \overline{970}$, Part I, Seri es 8189-192, 1975.

U.S. Bureau of the Census, Statistical Abstract of the United States, 1982-83, Table 109, 1982.

Enpl oynent and Trai ni ng Adni ni strati on, Enpl oynent and Trai ni ng Report of the Presi dent, 1981, Tabl e A 2, 1981. 


\section{The Health of the Elderly}

One of the big surprises of recent years has been the sharp reduction in age-specific mortality of older persons. Between 1965 and 1980 life expectancy at age 65 jumped from 14.6 to 16.4 years. This was a much bigger increase than was expected, based on extrapolation of either the 1935-65 or 1950-65 trends (see Table 2). The improvement is attributable primarily to a decrease in the risk of death from heart disease or cerebrovascular disorders (strokes), as may be seen in Table 3. Why death rates from these causes have plummeted is not well understood. Analysts who are technologically inclined attribute most of the reduction to better control of hypertension, special coronary care units in hospitals, open heart surgery, and similar medical innovations. Other observers credit changes in diet, smoking, exercise, and other aspects of personal behavior. We do not know the true explanation; there is probably some validity to both points of view.

Are people escaping fatal heart attacks and strokes only to spend more years in poor health? That question is difficult to study because measures of morbidity and disability lack the objectivity of mortality statistics, but in my judgment the answer is no. Restricted activity days and bed disability days per hundred persons 65 and over were about the same in 1980 as in 1965 [U.S. Bureau of the Census 1982]. The percent of persons reporting activity limitations due to chronic conditions rose somewhat from 1970 to 1980 , but it is doubtful that this is the result of greater morbidity. For instance, the percent of elderly persons reporting hypertension without heart involvement rose from 6.4 to 13.1 [U.S. Bureau of the Census 1982], but it is unlikely that hypertension actually increased. Indeed, direct measures of blood pressure among the elderly over the same period show declines in average levels and a large 
Table 2. Life expectancy at age 65, sel ected years 1935 to 2000.

\begin{tabular}{|c|c|c|c|c|c|c|c|}
\hline & & & 1935 & 1950 & 1965 & 1980 & 2000 \\
\hline Act ual & & & 12.5 & 13.9 & 14.6 & 16.4 & \\
\hline Predi cted & from 1935- 50 & trend & & & 15.5 & & \\
\hline Predi cted & from 1935- 65 & trend & & & & 15.8 & \\
\hline Predi cted & from $1950-65$ & trend & & & & 15. 3 & \\
\hline Predi cted & from $1935-80$ & trend & & & & & 18.5 \\
\hline Predi cted & from $1950-80$ & trend & & & & & 18.3 \\
\hline Predi cted & from 1965- 80 & trend & & & & & 19. 1 \\
\hline
\end{tabular}

Sources : Nati onal Center for Halth Statistics, Halth, United States, 1982, U. S. Covernment Printing Office, Decenber 1982, Tabl e 10.

Nati onal Center for Heal th Statistics. Vital Statistics of the Uni ted States, 1965, "Mortality, Pt. A," Tabl e 5-4, 1967.

U.S. Bureau of the Census, Historical Statistics of the United States, Col oni al Ti nes to $\overline{1970,}$ Seri es A 133, 1975.

Dubl i n, Loui s, Heal th Progress 1936-1945, A Suppl enent to TwentyFive Years of Halth Progress, Metropol itan Life Insurance Company, New York, 1948, Table 6.

U.S. Bureau of the Census, Statistical Abstract of the United States 1982-83, p. 71; 1982. 
Table 3. Age-specific death rates from heart and cerebrovascul ar di seases and other causes, 1965 and 1980.

\begin{tabular}{lllll}
\hline & & 1965 & 1980 & Change 1965 to 1980 \\
Age & Cause & (Deaths & per 100,000$)$ & \begin{tabular}{c} 
(percent per annum) \\
\hline
\end{tabular} \\
\hline
\end{tabular}

$\underline{65-74}$

Heart and cer ebrovascul ar di seases 2057 1433 $-2.4$

Oher causes 1606 1535

$-0.3$

$75-84$

Heart and cerebrovascul ar di seases $5261 \quad 4065$

- 1.7

aher causes 3098 3113

0.0

85 and over

Heart and cer ebrovascul ar di seases $13256 \quad 9229$ $-2.4$

ather causes 6813 5261 $-1.7$

Source: Nati onal Center for Heal th Stati stics, Health, United States, 1982, U. S. Governnent Pri inting Offi ce, Decenber 1982, Tabl es 9, 16, 19. 
decline in the percent of the population 65-74 with systolic pressure of 160 or nore or di astol i c pressure of 95 or nore [Nats 1981 and 1982a]. Taki ng al I the avai I abl e nortal ity and norbi di ty data i nto account, I concl ude that the health status of the elderly at any gi ven age has i nproved in recent decades and that this improvenent is primarily the result of lovered inci dence or severity of heart di sease and cer ebrovascul ar di sease.

. Death rates from all other causes at ages 65-84 vere virtually the sane in 1980 as in 1965. This relative stability presents a mjor puzzle. During those years Medi care substanti al ly i mproved access to heal th care for the elderly, especially the poor. Also, there were many significant nedi cal advances i ncl udi ng new drugs, i mproved surgical procedures, and enhanced diagnostic techniques. It is difficult to believe that these achi evenents had no benef $i$ ci al effect. Age-adj usted death rates from mal ignant neopl asns (cancer) actually rose between 1965 and 1980 anong the el derly, possi bl y as a resul $\mathbf{t}$ of i ncreases several decades ago in cigarette snoki ng and envi ronmental hazards. It is encouragi ng to note that cancer nortal ity has declined for males 35-44; perhaps similar declines will begin to show up at ol der ages as the cohorts with fewer cigarette snokers reach that poi nt in the life cycle.

VII I Ife expectancy at older ages continue to increase at a rapid rate? Sone experts say 'no," arguing that there is a biologically deternined average I i mit for the species of about 85 years [Fries 1980]. Oher observers contend that recent Iarge declines in the death rate for the $85+$ group is evi dence agai nst the existence of that I i int [Schnei der and Brody 1983]. Both groups agree that additional declines in nortality at ages 65-84 are possible or even likely; it would, therefore, be prudent to consider the possibility of such declines in planning future prograns for the elderly. 
Heal th Care Utilization

The role of addi ti onal medical care in i mproving the heal th of the el derly is a matter of sone di spute. What is beyond di spute is the i ncreased consumpti on of nedi cal servi ces by the el derl y. Bet ween 1965 and 1981 there was a I arge increase in health expenditures at al age level s, but the share accounted for by persons 65 and over jumped from 23. 8 percent to 32.7 percent. This shift has hel ped to fan the Medicare fi nancial crisis; it is, therefore, inportant to examine it in some detail. Tuo factors are responsible and they have been about equal in inportance: first, the number of elderly grew nore rapidly than the rest of the popul ation; second, the change in per capita health expenditures by the elderly outpaced the rate for persons under 65 ( see col um 1 of Table 4). The rel ati ve i mportance of these factors was not the sane anong the subperi ods, however, as ma be seen in col ums 2-4. Not surprisingly, per capi ta expenditures anong the elderly rose rapidly in the years imediately after the enactnent of Medicare (1965-70). From 1970 to 1976 per capi ta expenditures rose at about the same rate for both age groups; di vergent trends in popul ation accounted for nearly al I of the differential change in expenditures.

During 1976-81, however, a large differential in the grouth of per capita expenditures agai $n$ energed. This gap, conbined with a continuing difference in population trends, resulted in a total differential change in expenditures of 3.8 percent per annum This was I arger than the difference between the el derl $y$ and the rest of the popul ation in the five years i mmediatel $y$ fol I owing the introduction of Medi care!

The I ast eight rous of Table 4 provide additional detai I regarding the surge of spending on the elderly. We see that there was a very sharp 
Table 4. Rates of change of health care expenditures, by age. 1965-81 (percent per annum).

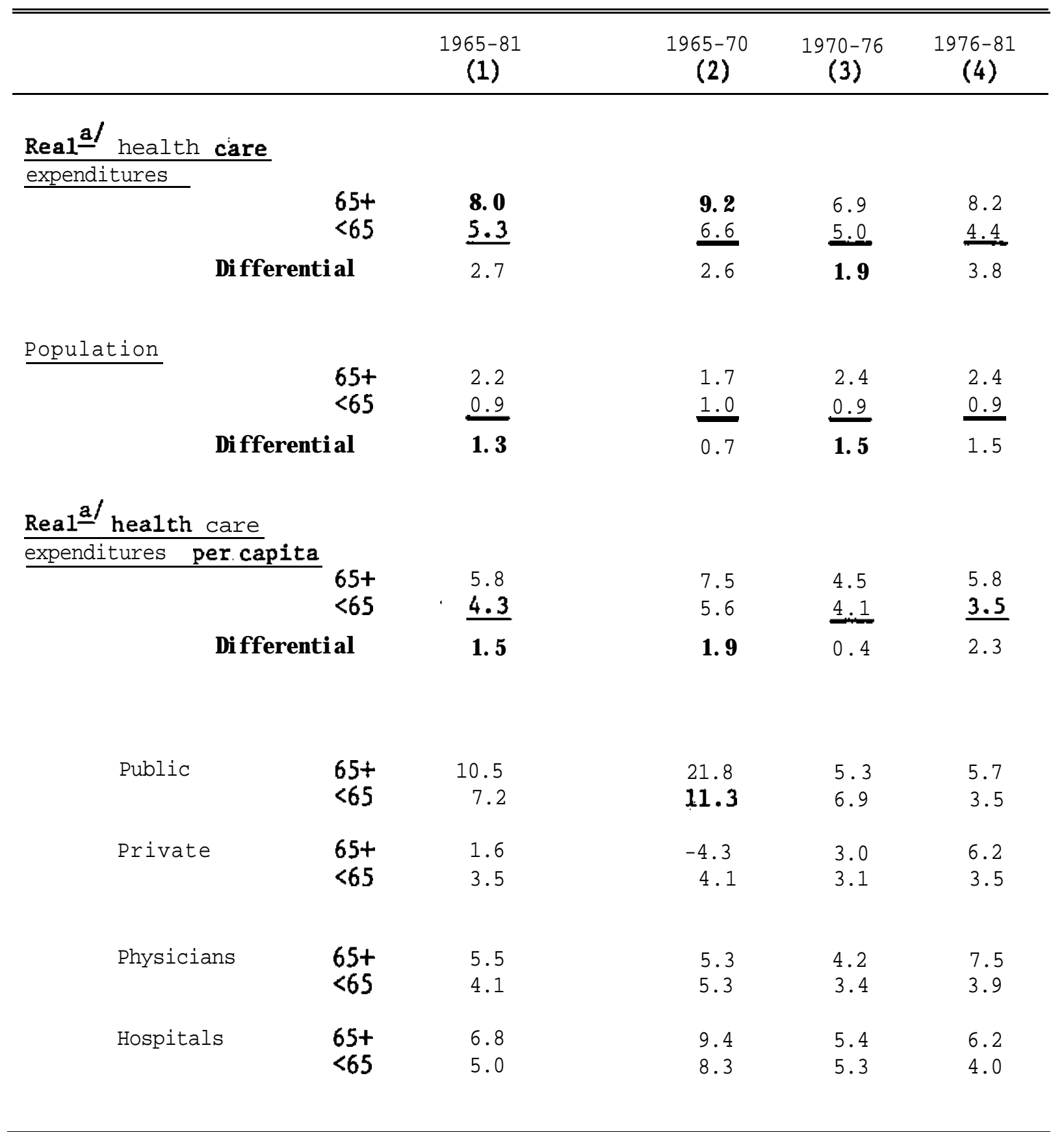

a/ Adjusted for inflation by the Gross National Product deflator.

Sources : U.S. Bureau of the Census, Current Population Reports, Series P-25, No. 519 and 917, Table 2

Council of Economic Advisers, Economic Report of the President, 1982, Table B-3.

Fisher, Charles R., "Differences by Age Groups in Health Care Spending," Health Care Financing Review, Vol. 1, No. 4 (Spring 1980), pp. 65-90, Table A.

Provisional data from the Health Care Financing Administration. 
decel eration in publ ic spending on persons under 65, while the trend i ncreased sl i ghtl y for the el derly. Pri vate spendi ng, on the other hand, hel d steady for persons under 65 and accel erated sharply for those over that age. With respect to type of expenditure, it was physicians' services that experienced the nost rapid increase anong the el derly.

What accounts for these di vergent trends? One possi bility is that i ncreasi ng competition anong physi ci ans for patients l ed nore of them to concentrate on the older nen and wonen in their practice. Another possibility is that the new nedical and surgical interventions have been particul arly appl i cabl e to ol der persons. These specul ations indicate why it is so difficult to predict expenditures on nedical care, either in the aggregate or for particular age groups or particular types of service. Sudden advances in nedi cal technol ogy--new drugs, new di agnostic techni ques, new surgical procedures-- can dranati cal l y al ter uti l i zati on. I n addi ti on, nod fi cati ons in insurance coverage, or in rei nbursenent nethods, or in the number of physi ci ans can alter the bal ance of demand and supply, thus inducing changes in the way physicians treat patients and the way patients use physicians. Whatever the cause, the upsurge in per capita expenditures of the elderly is a mjor factor in the prospective deficits in Medicare.

\section{Does utilization rise with age? Analysts interested in projecting}

future health care utilization by the el derly have frequently noted that the age di stribution within the 65-and-over group is shifting toward the ol der ages and that utilization (as reflected by Medicare rei nbursenents) ri ses steadily with age ( see fi rst three col unns of Table 5). Under the assumpti on that the cross-sectional age-spending rel ationship hol ds constant over ti ne, the effect of the change in age distribution is esti nated by 
Table 5. Rei nbursenent per Medicare enrollee by age and sex, 1976 (dollars).

\begin{tabular}{|c|c|c|c|c|c|c|}
\hline & \multicolumn{3}{|c|}{ Actual } & \multicolumn{3}{|c|}{ Adj usted } \\
\hline & $\begin{array}{l}\text { A I } \\
(1)\end{array}$ & $\begin{array}{l}\text { Men } \\
(2)\end{array}$ & $\begin{array}{c}\text { Wbnen } \\
(3)\end{array}$ & $\begin{array}{l}\text { A I } \\
(4)\end{array}$ & $\begin{array}{l}\text { Men } \\
(5)\end{array}$ & $\begin{array}{c}\text { Wbnen } \\
(6)\end{array}$ \\
\hline $67-60$ & 518 & $57 \%$ & 471 & 624 & 654 & 595 \\
\hline 69- 70 & 555 & 613 & 511 & 649 & 667 & 630 \\
\hline $71-72$ & 603 & 674 & 551 & 679 & 704 & 660 \\
\hline 73- 74 & 657 & 717 & 613 & 712 & 713 & 705 \\
\hline 75- 79 & 736 & 793 & 699 & 732 & 716 & 742 \\
\hline $80-84$ & 818 & 854 & 798 & 717 & 679 & 741 \\
\hline $85+$ & 666 & 937 & a32 & 595 & 594 & 595 \\
\hline
\end{tabular}

Source: Heal th Care Fi nancing Administration, office of Research and Denonstrations, Heal th Care Fi nanci ng Program Stati stics "Medicare Sunary, Use and Rei nbursenent by Person, 1976- 1978, " August 1982, Bal ti nore, MQ pp. 53 and 61 . Adj usted expenditures cal cul ated by author. 
applying the cross-sectional data on age-specific expenditures to the change in the age di stribution.

A though this procedure is widely used, implicitly if not explicitly, it is incorrect. To the extent that the change in the age distribution is the result of rising life expectancy (i.e., falling age-specific death rates), the cross-sectional differences in expenditures by age overestimate the changes that uoul d resul $t$ from an agi ng popul ati on. Heal th care spendi ng anong the elderly is not so mach a function of tine since birth as it is a function of time to death. The principal reason why expenditures rise with age in cross-section (anong persons 65and over) is that the proportion of persons near death increases with age. Expenditures are particularly I arge in the Iast year of I ife, and, to a I esser extent, in the next-to-I ast-year of I i fe. Anong Medi care enrol lees in 1976, the average rei nbursenent for those in thei $r$ I ast year of Iife was 6.6 ti nes (and in thei next-to-last-year of life 2.3 ti nes) as I arge as for those who survived at least two years [Lubitz and Prihoda 1982]. As age-specific death rates fall over ti ne, there will be fewer people in the Iast year of Iife in any age category, and this wil tend to reduce age-specific health care expenditures.

Age-sex-specific expenditures adjusted for age-sex differences in death rates can be calculated by a nethod anal ogous to the indi rect nethod of cal cul ating age-sex adjusted death rates. Suppose that each person's expendi tures depended onl y on thei r survival status, e.g., I ast year of I ife, next-to-l ast year, or "survivor." he can esti mate a "predicted" expenditure for each age-sex group by mul ti pl yi ng the proportion i n each survi val status by the all-group average expenditure for each survi val status and suming across the three statuses. The higher the death rate of the group, the 
hi gher noul d be its "predi cted" expendi tures. The ratio of actual to "predicted" expenditures for a group tells us whether expenditures are rel ati vel y hi gh or l ow after adj usting for its death rate. This ratio mul tiplied by the average expenditure for al I groups yi elds the adjusted expendit ture for the group. I/

As may be seen in the last three col ums of Table 5 and in Figure 1, adj ustnent for age-sex differences in survi val status el iminates nost of the age-rel ated increase in expenditures, especially the very high expenditures in the S-and-over group. It al so el iminates the excess of mal e over femal e expendi tures at gi ven ages. The onl y reason why ol der nen use nore nedical care than ol der wonen at any given age is because a higher proportion of the nen are in thei $r$ last year of life.

I do not clai $\mathrm{m}$ that there is no effect of aging on health care utilization apart from the proxi mity to death, but much of the apparent effect is attri butabl $e$ to the rel ati onshi $p$ bet ween age and nortal $i$ ty. This

$$
\begin{aligned}
\text { I/Let } \mathbf{X} & =\text { expendi tures per person } \\
N & =\text { nunber of persons } \\
\mathbf{P} & =\text { predi cted expendi tures per person } \\
X^{\prime} & =\begin{array}{l}
\text { expendi tures adj usted for age-sex di fferences in } \\
\text { survi val }
\end{array} \\
. g & =\text { age-sex group } g \\
\mathbf{t} & =\text { al I age- sex groups } \\
s & =\text { survi val status } \underline{s} \\
u & =\text { al I survi val statuses } \\
X_{u g}^{\prime} & =\frac{X_{u g}}{P_{u g}} X_{u t} \quad \text { uhere } P_{u g}=\frac{\sum_{s} X_{s t} N_{s g}}{\sum_{s} N_{s g}}
\end{aligned}
$$




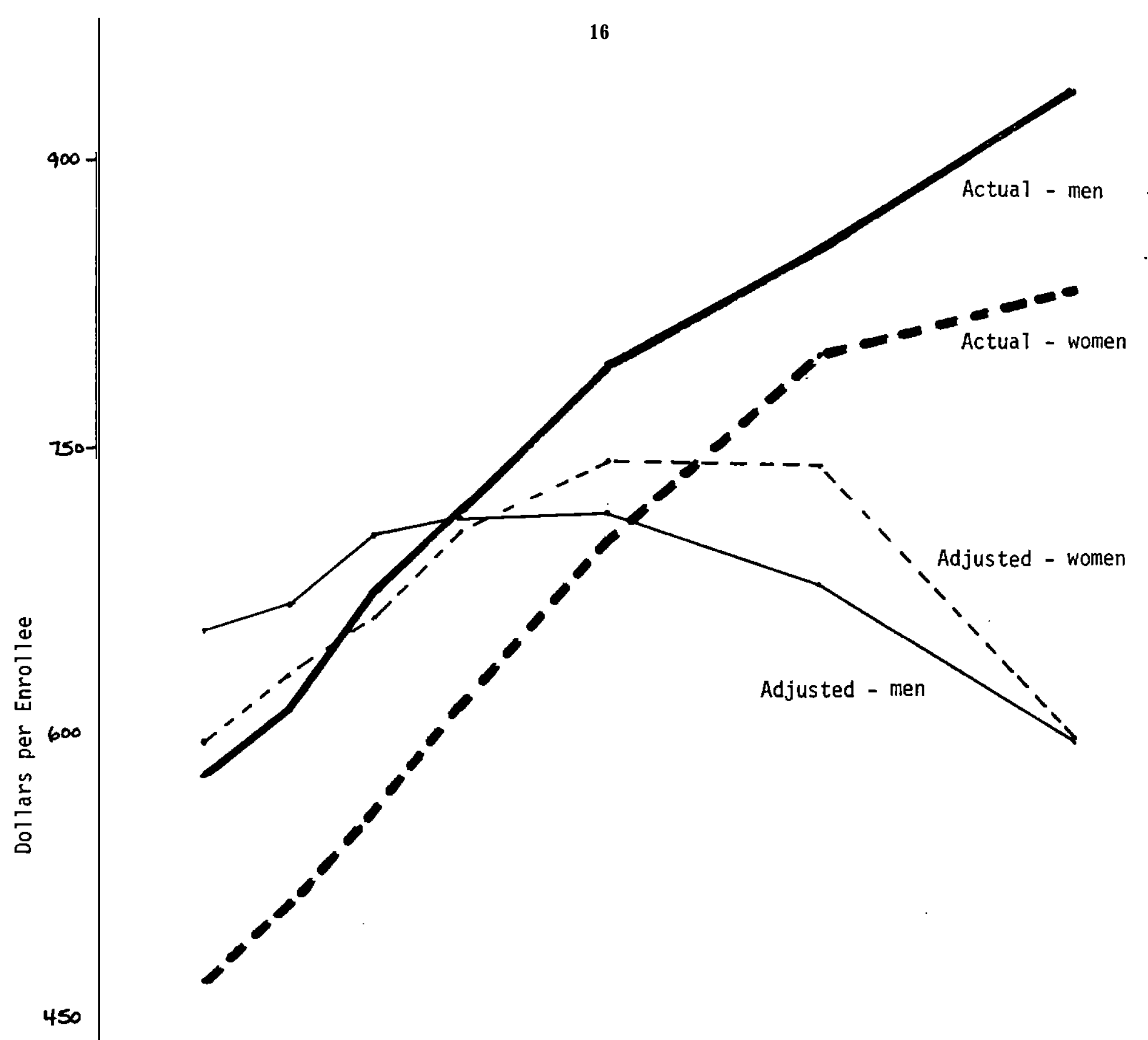

Fi gure 1. Medicare rei nbursenent per enrollee by age and sex, actual and adj usted for survi val status, 1976. 
observation nould be of little consequence if nortality rates were constant over ti me, but they are not. Between 1965 and 1978 the age-adj usted death rate of persons 65 and ol der fell from 65 per 1,000 to 53 per 1,000. If age-specific death rates continue to fall at this rate, 75-year-olds in 1987 will face the sane probability of death as 71-year-olds faced in 1965.

How much heal th care will 75-year-0lds utilize in 1987? The ansuer w' I I depend upon many factors, i ncl udi ng changes in nedi cal technol ogy, the strengthening or veakening of fanily support systens, and revisi ons in Medi care rei nbursenent pol i ci es. But to the extent that fewer 75-year-ol ds will be in the Iast or next-to-last year of life, a si mple extrapolation from past utilization of 75-year-olds is i nappropriate.

Kenneth G Manton [1982] reaches a si milar concl usi on from a nodel that emphasizes the distinction between the hypothetical age trajectory of nortality risk for individuals and the age trajectory for a cohort. He writes "As nortality rates decline at a given age, there uould be sone compensating decline in the rate of utilization of certai $n$ heal th services (e.g. . nursing hone care) before that age. In fact, such nodels night be used as the basi s for i mproving projections of heal th service utilization by providing estimates of the likely change in heal th-service-utilization rates associated with a gi ven nortal ity reducti on" [Manton 1982, p. 205].

The rel ati onships bet ueen utilization, age, and survi val stat us will depend on the reasons for the I over death rate. If nortal ity fal Is because people are living heal thi er lives or because of nore effective preventive neasures, the conventional extrapol ations will over-estimte heal th care utilization. as denonstrated above. On the other hand, if the lower death 
rates are the result of ever nore compl ex technol ogi cal interventions, the rising cost of such interventions will tend to of fset the fact that fever persons are in the last year of life.

Labor Force Parti ci pati on

Between 1950 and 1980 the Iabor force participation rate of nen 65 and over fell from 46 percent to 19 percent. Participation rates of nen 55- 64 have al so dropped sharply in recent years, from 83 percent in1965 to 72 percent in 1980. What accounts for these striking decl i nes? Many expl anati ons have been offered, i ncl uding poor heal th, mandatory reti renent rul es, age discrimination, ri si ng uages, and i mproved soci al security benefits.

Health. When older nen are surveyed about their labor force status, those not partici pating frequently cite ill heal th as the reason. These replies have been vi ened with sone skepticism because ill heal th may be offered as a socially acceptable reason for not working when the true expl anati on li es el sewhere. A I ongi tudi nal anal ysi s of reti renent patterns, however, reveal ed that poor health is a good predictor of which nen currently at nork will not be norking four years Iater [Fuchs 1982]. This rel ationshi p does not, however, expl ai $n$ why partici pation 
by ol der nen is so much I ower now than it was 30 years ago. As noted, the heal th of the el derly has probably inproved, and the occupational structure has shifted away from bl ue collar jobs requi ring heavy physical exertion. Thus, at any given age probably fever men are compel led to I eave the I abor force for heal th reasons now than i $n$ earl i er decades. Ther ef ore we must I ook to other factors.

Mandatory reti renent and age discrimination. According to sone popul ar di scussions, nen stop uorking because of mandatory reti renent or because they are vi cti ns of age di scri mati on. I $\mathrm{n}$ my judgnent nei ther of these explanations has been a significant factor in the I ong-term downward trend in Iabor force participation. First, about half of all currently reti red nen were never subject to mandatory reti renent rul es [Schulz 19761. Furthermore, many workers retire before the mandatory age, many reti re willingly at the mandatory age, and sone are not uorking for other reasons such as ill health.

Mandatory reti renent rules are usually part of a total labor contract, ei ther explicit or inplicit, that provides uorkers with stable or even rising uages unti I retirenent, even though thei $r$ productivity ma decline during thei $r$ I ast years of empl oyment. If ol der workers are being pai d nore than they' re currently uorth, when they lose thei $r$ jobs through mandatory reti renent they obvi ously have difficulty obtaining a new job at thei $r$ old uage rate.

The gap that devel ops between the uages of sone ol der workers and thei $r$ productivity is one reason why wear conplai nts about "age di scri mi nation." It is obvi ous that many enpl oyers prefer younger to ol der 
norkers, but this is not "discrimination" in an econonic sense if age affects producti vity or I abor costs. For instance, the ol der uorker my expect a higher wage even though his productivity does not justify the wage differential. Even if there is no uage-productivity gap, the fri nge benefits of older norkers are often rel atively high, especially for health insurance, Iife insurance, and pensi on benefits. As the share of fringe benefits in the total conpensati on package increases, it becones i ncreasingly unecononic for fi rns to hi re older uorkers. If there appears to be nore age di scrimination now than there was 30 years ago, it is probably because of the changes in uages and fringe benefits that make it less attractive to hire ol der workers.

Decline of self-empl oyment. One factor that probably does contribute to the downward trend in participation by older nen is the declining i mportance of self-empl oynent. Self-enpl oyed men are nore likely to conti nue norking at ol der ages than are uage-and-sal ary uorkers, hol di ng constant educati on, age, heal th, uages, and other rel evant vari abl es [Fuchs 1982]. Whe-and-sal ary uorkers typically face nore rigidity in hours and uages, while the self-empl oyed find it easi er to reduce thei $r$ hours of uork without changing thei $\mathbf{r}$ occupation or $\mathbf{j}$ ob. The proportion of uorkers who are self-enpl oyed has declined drastically throughout the 20 th century because of the shi ft of empl oynent fromagri cul ture to i ndustry and servi ce. Even within each sector, self-employment has declined in relative importance as smal I farns and smal I busi nesses find it increasingly difficult to conpete with I arger enterprises.

Real uages. Sone economists argue that the grouth of real uages in the econony as a whole is a major reason for the decline in iabor force partici pation of ol der nen, al though this conclusion does not fl ow di rectly 
from econonic theory. An increase in participation nould be equally consistent with theory because the higher the uage, the higher the price of not working. But hi gher wages al so mean higher incone and the incone effect increases the demand for leisure. It is difficult to predict whether the price or incone effect will doninate.

For uonen of prine norking age higher real wages have resulted in nore I abor force participation, not l ess. In the case of ol der nen, however, it appears that the incone effect is I arger than the price effect. This nould expl ai $n$ why the labor force participation of older nen has declined in the United States as real incone has risen. One problem with this explanation is that participation rates of older nen in Europe are as low as in the Uni ted States, even though real i ncone is not as high. To be sure, these countri es typi cal I y have generous publ i c pensi onpl ans that faci li tate reti renent. But why do they have such pl ans? The i ncreasi ng number of el derly nay be the answer, partly because of the political power that nunerical strength confers and partly because younger uorkers want the ol der ones to I eave the Iabor market.

Nunber of el derly. The grouth in the proportion of el derly probably contributes to thei $r$ low participation rate. When there are relatively few ol der people, the population has a pyramidlike age structure similar to the hi erarchical structure of nost organizations; the rel ativel $y$ few ol der norkers can nore easi I y progress up the organi zati onal I adder. Current l y in the United States and in nost European countries the age distribution is nore rectangular in shape, but organizations still have a pyranidfike hierarchy with fewer and fewer openi ngs the hi gher up one goes. Thus if nost ol der norkers stayed in the Iabor force, they would find it impossible to nove up wi thi n thei $r$ organi zati ons. 
Social Security. Probably one of the nost important reasons why the I abor force participation of ol der men has declined so rapidly is the unusual grouth of social security benefits. Bet neen 1970 and 1980 average reti renent benefits (adjusted for inflation) increased by nore than 3 percent per annum while hourly earni ngs did not even keep pace with inflation. There is no doubt that public policy has made it increasingly attractive for ol der peopl e to stop work--by increasing reti renent benefits rel ative to uages, by offering an early retirenent option at 62 , and by withhol ding benefits from eligible retirees at the rate of 50 cents per dollar of earnings on earni ngs above a prescribed rate.

The trend toward earlier retirenent, conbi ned with greater life expectancy, will place a trenendous burden on those vorkers who remin in the I abor force (as noted on page 3). To reverse this trend, however, wil I probably requi re maj or changes in the structure of jobs and Iabor markets as vel $\mathrm{l}$ as changes in the structure of social security retirenent benefits.

Incone

Froma purel y fi nanci al perspecti ve, today's ol der Aneri cans are much better off than thei $r$ predecessors. They have nore incone and nore neal th (adjusted for i nflation) than any previous generation of el derly. Thei r real incone has risen not onl y in absol ute terns but al so rel ative to the incone of the uorking population, prinarily because of the rapid grouth of social security retirenent benefits. It is true that household i ncone when the househol der is 65 or over is onl $y$ hal $f$ of that in the age range 45 to 64 , but this figure must be adj usted for household size. 
In 1980 the househol ds of the el derly had on average only 1.74 persons, compared with 2. 83 persons when the househol der is 45- 64. Taxes al so make a big difference. The el derly's taxes (federal and state indi vi dual i ncone taxes, property taxes on owner-occupi ed housing, and payroll taxes) are esti nated to be onl $y$ percent of thei $r$ incone, while the 45-64 age group pay taxes equal to about 25 percent of incone [U.S. Bureau of the Census 1983]. Thus the after-tax incone per househol d nenber of the el derly is al nost equal to that of the 45-64 age group.

Nbt only does the average older person receive an after-tax incone conparable to that he or she recei ved at younger ages, but incone is nore Equably wistsi buted dftee age 65 thanh befere that age. I $\quad$ I 0 w anal ysi s of i ncones based on the Reti renent History Survey, a I ongi tudi nal st udy of approxi matel y 11, 000 i ndi vi dual s [ Hurd and Shoven 1983]. In 1968 when the respondents were 58 to 63 years of age and nost were still in the I abor force, the weal thi est 10 percent of the sample had a nean incone of $\$ 65,363$ (all figures in 1982 dollars), while the poorest 10 percent recei ved onl y \$1,838. By 1978, however, at ages 68 to 73, with nost of the sanple in reti renent, the mean incone of the veal thi est 10 percent had fallen to $\$ 52,117$ while the poorest 10 percent showed a $\underline{\text { rise }}$ in incone to $\$ 4,070$. The principal reason for the narrowing of i nequality after 65 is that social security benefits becone nore important and I abor incone less important, and the forner is distributed much nore equally than the Iatter.

The inprovenent in the incone position of the poor elderly has been particularly striking. As recently as 1970 one out of four persons 65 and over was bel ow the poverty I evel, while the proportion anong persons under 65 was about one in eight. In 1982 the proportion was the same for both age groups--about one in seven. 
To be sure. noney incone is only one neasure of econonic vell-being, but consideration of other factors tends to strengthen the impressionthatthe elderly are, on average, about as vel I- of $f$ as other age groups. For instance, , persons over 65 are nore I i kel y to own a house free and cl ear of any nortgage. A so, the el derly recei ve a disproportionate share of non-cash transfers such as subsi di zed housi ng, transportati on, and nedi cal care. Because they are typically not in the Iabor force they have nore time for hone production activities such as gardening, repai $r$, and mi ntenance; they experience feuer work-rel ated expenses such as commiting and neals away from hone, and they have the opportunity to nove to a less costly area of the country.

One di sadvantage faced by the elderly is the snall size of the typical househol d. In 198044 percent of their househol ds had only one person, and 46 percent had only two. Snal househol ds are usually not as efficient as I arger ones in the use of space, equi pnent, food, heat, and Iight. The difficulties and disadvantages of doubling up with another older person in order to gai $n$ the economies of a I arger household are, however, apparently consi derable. Fever than 2 percent of el derly househol ds i ncl ude nenbers who are unrel ated, despi te efforts by social agencies to encourage shared housi ng.

A though nost of the elderly receive an after-tax incone that conpares favorably with what they earned while at uork, there is a dranatic change in the source of incone after age 65. From ages 25 to 54, earni ngs account for nore than 90 percent of the total, and between 55 and 64 they still account for 78 percent of i ncone. For people over 65, however, earnings provide onl y 20 percent. Social security reti renent benefits are the nost inportant other source, with capital incone such as interest and di vidends next in 
i mportance, fol l oved by governnent empl oyee pensi ons, pri vate pensi ons, and publ i c assi stance.

Does the source of i ncone matter? I thi nk it does. Social security reti renent benefits and other annuity-like incone does not flow from assets which the older person can pass on to children or consune at a pace that he or she deternines. In an earlier era the aged had less total incone relative to younger people than they do today, but nore of it cane from farns or snal I busi nesses or bits of real estate that they owned. Onnership usually contributes to a sense of power and control and can affect intra-family rel ati onshi ps. A recent anal ysi s of frequency of visits by children to thei $r$ el derly parents found that the number of visits uas positively related to the parents' bequeathable meal th (e.g., stocks, bonds, bank accounts, real estate), but not to non-bequeathable veal th (e.g., soci al security, private pensi ons) [ Bernhei m Shl ei fer and Surmers 1983]. If seni ors today are "doing better and feeling uorse," it may in part be because of this loss of control over thei $r$ economic assets. 
Living and Dying

A wide variety of demographic, social, and economic forces have resulted in major changes in how the elderly live and die. For instance, the male-female differential in death rates and the tendency of older widowed and divorced men to choose younger wives when they remarry create a large surplus of unmarried women above the age of 65 . This surplus has grown in recent decades because female life expectancy has grown much more rapidly than male. In 1980 there were almost four unmarried women 65 and over for every unmarried man of that age, a steep increase from a ratio of less than two to one in 1940. The greatest change occurred among the widowed. In 1940 there were approximately two elderly widows for every widower, but by 1980 there were more than five. The huge rise in the number of elderly widows has been accompanied by a dramatic change in their living arrangements. In 1950 one in four was living alone; the other three were living with children, other relatives, or friends. By 1980 two out of three widows 65 and over were living alone, and only one in three was sharing living quarters with someone else. Most elderly men are married. Even at ages 75 and above, two out of three men are living with their wives, but only one woman in five has a husband.

There has been a great deal of hand-wringing about the decline of three-generation households, but historians have hastened to point out that in Western Europe and the United States the three-generation household has always been the exception, not the rule. We can accept their conclusion that most households did not contain an aged mother or father, but it does not follow that only a small fraction of aged men and women lived with their children. When mortality is high and the population is growing rapidly, it is 
possible for nost of the elderly to Iive with thei $r$ children even though onl y a minority of chi I dren have el derly parents I i ving with them For exampl e, if each uonan has two daughters, and if half of the wonen survive into ol d age, only one daughter in four uould have her nother Iiving with her, even if every one of the survi vors uere I i vi ng with a daughter. As an indication of how I onger life expectancy and falling bi rth rates have rai sed the nother-to-daughter rati 0 , the number of uonen 65 and over rel ati ve to those 35-44 doubl ed between 1950 and 1980.

In addition to these denographic changes, rising real incone contributes to the decrease in the number of nothers who double up with their children [Mchael, Fuchs, and Scott 1980]. Anericans of all ages have al uays put a high val ue on autonomy; therefore, the rising incone of recent decades and the particularly rapid rise in the incone of the elderly have made it possible for an ever higher percentage of them to mintain thei $r$ own househol ds, heal th pernitting.

Heal th is al so an i mportant factor in I i vi ng arrangenents. In earlier tines, poor heal th was often the reason why ol der men and wonen noved in with thei $r$ children. At present, poor health often results in a nove to a nursing hone. The number of el derly in nursing hones increased at an astoni shing 7 percent per annum between 1963 and 1977, to a total of over $1.1 \mathrm{milli}$ on. On any gi ven day 5 percent of al l el derl y li ve i n nursing hones, and between 20 and 25 percent will do so at some point in thei $r$ lives. of those who do enter, only one in four returns to a private or semiprivate residence; one-half are transferred to another health facility (usually a short-term general hospital), possibly to die or to return to the nursi ng hone. 
Why have nursi ng hones becone so i mportant? Ri si ng i ncone, the increased propensity to Ii ve al one, higher nother-to-daughter ratios, and hi gher I abor force partici pation rates by young and middle-aged uonen are all part of the ansuer. There are many nore elderly people who need care and attention, and relativel $y$ fewer children who are providing it within the hone. Public policy al so influences the decision because frequently nursing hone care is paid for by governnent ( 57 percent of the total in 1981), but the cost of hone care is borne nostly by the fanily through out-of-pocket expenditures and the foregone earnings of the caregi ver.

Econonic and social factors also affect the location and manner of death. According to a report from the National Center for Heal th Statistics (1982b), 62 percent of deaths of persons 65 and over occur in a hospital or nedical center, often at great cost. In sone cases the patient is hospitalized because there is a reasonable chance to postpone the death through the kinds of nedical intervention that are only possible within a hospital setting. In other cases, however, the patient is taken to the hospital to die because public and private insurance pays nore fully than if the dying person is cared for at hone. And in still other cases, there is no one close enough, either geographically or enotionally, to offer any al ternative to hospitalization.

The cost of caring for very ill patients can vary enornously, depending upon the pati ent and the physi ci an [Garber, Fuchs, Si I verman forthcoming]. In sone cases the intensi ve application of nodern technol ogy can prolong life for one or two nonths or perhaps even nore. This type of decision has traditionally been l eft to the patient and his or her physician, but expl odi ng costs ma l ead to a reexami nation of that position. At a nini mum there will be a search for less costly al ternatives, and a closer exani nation of the factors that influence such deci si ons. 


\section{A Fi nal Note}

The data presented in this paper and the acconpanying di scussion are neant to be suggestive, not definitive. Large gaps in our understanding of the aging process and of the determinants of I abor force participation, heal th care utilization, and other key variables make it difficult to draw fi rm concl usi ons. It my be useful, hovever, to state explicitly sone of the maj or thenes that are i mpl i cit in the preceding pages. Most i mportant is the need to recognize that the "Medicare problem" reflects the intersection of two I arger sets of issues. First, there are a range of questions concerning the elderly in general: questions of retirenent benefits, age of eligibility, wages and hours of nork, and the li ke. Second, there are questi ons concerni ng the fi nancing, organization, and del ivery of heal th care for persons of al I ages. Any Medi care "sol uti on" that fails to consi der these I arger issues will probably turn out to be counter-productive.

A so inplicit in this paper is the need to recognize that resources devoted to the elderly are resources that could be used to help children, teenagers, minorities, and other groups with special clains to public attention. To say this is not to deny that there are many el derly who are poor, si ck, I onel y, or otherwise di sadvantaged. But the growing political power of the elderly suggests the possibility of disproportionate attention to this group at a ti ne when many small children are neglected or abused, when the schools are at a low ebb, and when teenage sui cide is at epi denic proportions.

Tuenty years ago the plight of the el derly was pal pabl e. Today the nost pressing social needs my lie el sewhere. The "good soci ety" needs to bal ance its efforts, to make hard choices anong many worthwhile objectives. 
These considerations, and the data presented in this paper, lead ne to hazard three i nf erences that have di rect rel evance for pol i cy. Fi rst, we need to peri odi cally revi se our definition of who is ol d. One way to do this is to focus on changes in life expectancy at ol der ages. For instance, in 1935 when the age of eligibility for social security retirenent benefits was set at 65, Iife expectancy at that age was 12.5 years. In 1984 the average 72-year-old has that sane life expectancy. From that point of vi ew it is not unreasonable to say that if 65 marked the entry into old age in 1935, in 1984 old age begins at 72.

Second, we need to devel op nore flexible labor market arrangenents to facilitate the conti nued Iabor force participation of older men and uonen. Unl ess this happens, the ratio of uorkers to retirees will becone so snal I as to pose a grave threat to our economy and our soci ety. Si mpl y passing I aus agai nst mandatory reti renent and age discrimination will not solve the problem need to devel op nore flexibility in hours of work, in uages (to accommodate possible age-rel ated declines in productivity), and in amount of responsibility (to speed the novenent of younger nen and wonen into positions of l eadership withi $\mathbf{n}$ organi zations).

Fi nal Iy, and this may Prove to be the nost difficult task of al I, we need to reach a soci al consensus concerning what is appropriate care for the dying. At present the Uni ted States spends about one percent of the gross national product on heal th care for elderly persons who are in thei $r$ last year of life. This is much nore than the nation spends on institutional care for the nentally ill and the nentally retarded of al I ages, nore than private and publ ic expenditures for basic and applied research in all fields, and nore than the total expenditures of al I the 
pri vate col I eges and uni versi ti es in the country. On the other hand, it is less than is spent on al cohol, and not much nore than is spent on tobacco. How mach should be spent on care for the $1.3 \mathrm{milli}$ on elderly persons who di e each year? For nost goods and servi ces our soci ety ansuers thi s questi on by sayi ng "Let the market deci de." According to econonic theory the free choice of knowl edgeable buyers paying with thei $r$ own noney for services rendered by competitive suppliers should result in a socially efficient allocation of resources. It will not necessarily be a " $f$ ai $r$ " al l ocation, but this problem is supposed to be addressed through redistri bution of i ncone, not di rect subsi di zati on of particul ar services.

Thi s free market approach is not I i kely to work wel I for the seriously ill. Patients and their fanilies are often under great enotional stress and they typically have little previous experience with the complex techni cal choices that must be made. The hospitals and physici ans who serve them of ten have consi derabl e nonopol y pover. Furthernore, even in the absence of publ ic subsi di es, private insurance nould push utilization beyond the poi nt where benefi ts are equal to cost. The probl em of di stri buti ve j ustice is not anenable to sol uti on through conventional incone redi stribution nethods because the anount soci ety uould want to gi ve to an indi vi dual uoul d depend on how much care they needed. Sone economists would prefer an i ndemi fi cati on plan that provides ol d peopl $\mathbf{e}$ with addi ti onal i ncone when they becone si ck and lets them deci de how much to spend for nedi cal care. Thi s planmay be a delight to sone theorists, but it noul d be a ni ght nare for nost pati ents and physi cians.

It is possible to ni bble at the edges of the problem by providing nore information to patients, by fostering nore competition anong providers, 
by fi nancing al ternative nodes of care for the dying, and by increasing deductibles and co-insurance. The fundanental problem hovever, will remin. One of the biggest chal lenges facing policy makers for the rest of this century will be how to strike an appropriate bal ance betueen care for the dying and heal th services for the rest of the population. 


\section{REFERENCES}

Bernhei $m$ B. Dougl as, Andrei Shl ei fer, and Lawrence H Summers. 1983.

"The Mani pul ati ve Bequest Mbti ve," ni neo (Stanf ord, MT, and Harvard).

Fri es, Janes F. 1980. "Agi ng, Natural Death, and the Compressi on of Mrbi dity,"

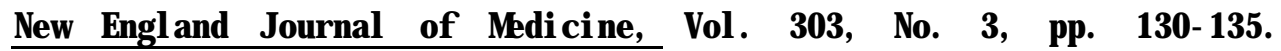

Fuchs, Vi ct or R. 1982. "Sel f-Enpl oynent and Labor Force Partici pation of O der Mal es, " Journal of Human Resources, Vol. 17, Nb. 3 (Summer), pp. $\quad 339-357$.

Garber, A an M, Vi ctor R. Fuchs, and J anes F. Si I verman. 1983. "Case M x, Costs, and atcones: Differences between Faculty and Community Servi ces in a Uni versi ty Hospital," NBER Wrking Paper 1159.

Hurd, M chael, and J ohn Shoven. 1984. "The Econonic Stat us of the El derly 1969-79," forthcoming in T. Sneeding and M H David (eds.), Horizontal Equity, Uncertai nty, and Measures of Well-Bei ng, NBER and Uni versi ty of Chi cago Press.

Lubi tz, J anes, and Ronal d Pri hoda. 1982. "Use and Costs of Medi care Servi ces in the Last Years of Life," mineo (Office of Research and Office of Stati stics and Data Managenent, Halth Care Fi nancing Adnini stration, Bal ti nore, Mryl and).

Manton, Kenneth G 1982. "Changing Concepts of Morbi dity and Mortality in the El derly Popul ati on," MI bank Menori al Fund Quarterly/ Halth and Soci ety, Vol. 60, Nb. 2 (Spring), pp. 183- 244.

Mchael, Robert T., Vi ct or R. Fuchs, and Shar on R. Scott. 1980. "Changes in the Propensity to Li ve Al one: 1950-1976," Denography, Vol. 17, Nb. 1 (February), pp. 39-56. 
Nati onal Center for Heal th Stati stics. 1981. Vital and Heal th Stati stics, Seri es 11, No. 221, "Hypertension in Adul ts 25-74 Years of Age, Uni ted St at es, 1971- 1975, Whshi ngt on, D. C. : U S. Governnent Printing office. - 1982a. Advancedata, Nb. 84, "Bl ood Pressure Level s and Hypertensi on i n Persons Ages 6- 74 Years: Uni ted States, 1976-80," Hyattsville, Mu.: Public Health Service. - 1982b. "Advance Report of Fi nal Mortality Stati stics, 1979," Monthl y Vital Stati sti cs Report, Vol. 31, Nb. 6, Suppl enent, Hyattsville, Mu.: Publ ic Health Service. Schnei der, Eduard L., and J acob A Brody. 1983. "Agi ng, Nat ural Death, and the Compressi on of Morbi di ty: Another Vi ew " New Engl and J ournal of Medi ci ne, 309, Nb. 14 (October 6), pp. 854-855.

Schul z, Janes $H$ 1976. The Econonics of Agi ng, Bel nont, Calif.: Whodsurth.

U. B. Bureau of the Census. 1983. Current Popul ati on Reports, Speci al Studi es, Seri es P-23, Nb. 126, "Esti mating After-Tax Mney Incone Di stributions Using Data from the March Current Popul ation Survey," Tabl e I, p. 12, Wishi ngt on, D.C. U.S. Covernment Printing Office. U.S. Bureau of the Census. 1982. Stati stical Abstract of the Uni ted States, 1982-83 (103d edi ti on), pp. 119 and 121, Wishi ngton, D. C. : U. S. Covernment Printing office. 
SOME RECENT NBER WORKING PAPERS

\begin{tabular}{|c|c|}
\hline Number & Author \\
\hline 1216 & $\begin{array}{l}\text { Robert G. King and } \\
\text { Joseph G. Haubrich }\end{array}$ \\
\hline 1217 & Alan J. Marcus \\
\hline 1218 & Steven Shave11 \\
\hline 1219 & Steven Shave11 \\
\hline 1220 & Steven Shavell \\
\hline 1221 & Robert J. Gordon \\
\hline 1222 & $\begin{array}{l}\text { Ronald G. Ehrenberg and } \\
\text { Robert S. Smith }\end{array}$ \\
\hline 1223 & Alan L. Gustman \\
\hline 1224 & John B. Taylor \\
\hline 1225 & John B. Taylor \\
\hline
\end{tabular}

1226 Richard B. Freeman

1227 Bronwyn H. Hall, Zvi Griliches and Jerry A. Heusmen

1228 J. David Richardson

1229 Raaj Kumar Sah and Joseph E. Stiglits

1230 Maurice Obstfeld and Alan C. Stockman

1231 Daniel S. Hamermesh and James M. Johannes
Title

Date

Sticky Prices, Money and Business Fluctuations

$10 / 83$

Corporate Pension Policy and the Value of PBGC Insurance

Liability for Harm Versus Regulation Of Safety

$10 / 83$

Uncertainty Over Causation and the

Determination of Civil Liability

$10 / 83$

A Model of the Socially Optimal Use of Liability and Regulation

$10 / 83$

The Conduct of Domestic Monetary Policy

$10 / 83$

Economic and Statistical Analysis of Discrimination in Hiring

Modeling Individuals' Behavior:

Evaluation of a Policymaker's Tool

Rational Expecations Models in

Macroeconomics

$10 / 83$

$10 / 83$

Optimal Stabilization Rules in a

Stochastic Model of Investment With

Gestation Lags

Unions, Pensions, and Union Pension

$11 / 83$

Funds

Patents and R\&D: Searching for a Lag Structure

$11 / 83$

U.S. International Trade Policies in a World of Industrial Change

The Social Cost of Labor, and Project

Evaluation: A General Approach

Exchange-Rate Dynamics

$11 / 83$

Food Stamps as Money and Income

$11 / 83$ 
Number $\quad$ Author

Title

Date

1232 Willem H. Buiter

1233 Joshua Aizenman

1234 Alan S. Blinder and Douglas Holtz-Eakin

1235 Stanley Fischer

1236 Jonathan Eaton and

Gene M. Grossman

1237 Alan L. Gustman and Thomas L. Steinmeier

1238 Jeffrey I. Bernstein and M. Ishaq Nadiri

1239 Don Fullerton, Andrew B. Lyon and Richard J. Rosen

1240 Jonathan S. Leonard

1241 Daniel J. Frisch and David G. Hartman

1242 Nicholas Carlozz1 and John B. Taylor

1243 Alex Kane and Young $\mathbf{K}$ Lee

1244 David A. Papell

1245 Sebastian Edwards and Sweder van Wijnbergen

1246 Jerry Green and John B. Shoven

1247 Mervyn King

1248 A ex Kane, Young K Lee and Alan J. Marcus
The Theory of Optimum Deficits and Debt 11/83

Openness, Relative Prices and Macro 11/83

Policies

Public Opinion and the Balanced Budget

$11 / 83$

Inflation and Growth

$11 / 83$

Optimal Trade and Industrial Policy

$11 / 83$

Under Oligopoly

A Structural Retirement Model

$11 / 83$

Does Knowledge Intensity Matter? A

$11 / 83$

Dynamic Analysis of R\&D, Capital

Utilization and Labor Requirements

Uncertainty, Welfare Cost, and the

'Adaptability' of U.S. Corporate Taxes

11183

Anti-Discrimination or Reveres Dis-

$11 / 83$

crimination: The Impact of Changing

Demographics, Title VII and Affirmative

Action on Productivity

Taxation and the Location of U.S.

$11 / 83$

Investment Abroad

International Capital Mobility and the

$12 / 83$

Coordination of Monetary Rules

The Forecasting Ability of Money Market

$12 / 83$

Fund Managers and its Economic Value

Activist Monetary Policy, Imperfect

$12 / 83$

Capital Mobility, and the Overshooting

Hypothesis

The Welfare Effects of Trade and Capital 12/83 Market Liberalization: Consequences of Different Sequencing Scenarios

The Effects of Interest Pates on

$12 / 83$

Mort gage Prepayments

The Economics of Saving

$12 / 83$

Earnings and Dividend Announcements:

$12 / 83$

Is There a Corroboration Effect? 


\begin{tabular}{|c|c|}
\hline Number & Author \\
\hline 1249 & $\begin{array}{l}\text { Richard B. Freeman and } \\
\text { James L. Medoff }\end{array}$ \\
\hline 1250 & $\begin{array}{l}\text { Laurence J. Kotlikoff, } \\
\text { John B. Shoven and } \\
\text { Avia Spivak }\end{array}$ \\
\hline 1251 & Claudia Goldin \\
\hline 1252 & $\begin{array}{l}\text { Willem H. Buiter and } \\
\text { Marcus H. Miller }\end{array}$ \\
\hline 1253 & Joshua Aizenman \\
\hline 1254 & $\begin{array}{l}\text { Richard C. Marston and } \\
\text { Stephen J. Turnovsky }\end{array}$ \\
\hline 1255 & $\begin{array}{ll}\text { Jeffrey } & \text { Sachs and } \\
\text { Charles } & \text { Wyplosz }\end{array}$ \\
\hline 1256 & $\begin{array}{l}\text { Michael Massourakis, } \\
\text { Farahmand Rezvani and } \\
\text { Tadashi Yamada }\end{array}$ \\
\hline 1257 & Alan S. Blinder \\
\hline 1258 & Herman B. Leonard \\
\hline
\end{tabular}

1259 Mark Schankerman and M. Ishaq

1260 Gary Solon

1261 Charles Brown

1262 Don Fullerton and Yolanda $K$. Henderson

1263 Jerry A. Hausman, Bart
D. Ostro and David A. Wise

\section{Title}

Date

Trade Unions and Productivity: Some 12/83 Ne't Evidence on an Old Issue

Annuity Markets, Savings, and the Capital Stock

$12 / 83$

Life-Cycle Labor Force Participation of 12/83 Married Women: Historical Evidence and

Implications

Costs and Benefits of an Anti-

Inflationary Policy: Questions and Issues

$12 / 83$

Tariff Liberalization Policy end 12/83

Financial Restrictions

Imported Mterials Prices, Wage Policy, 12/83 and Macroeconomic Stabilization

Real Exchange Rate Effects of Fiscal Policy

$1 / 84$

Occupation, Pace, Unemployment and Crime 1/84 In a Dynamic System

Can the Production Smoothing Model of $1 / 84$ Inventory Behavior be Saved?

The Federal Civil Service Retirement System: An Analysis of its Financial Conition and Current Reform Proposals

Restricted Cost Functions and the Rate of 1/84 Return to Quasi-Fixed Factors, with an Application to $R \& D$ and Capital in the Bell System

Work Incentive Effects of Taxing 1/84 Unemployment Benefits

Mlitary Enlistments: What Can We Learn $\mathbf{1 / 8 4}$ From Geographic Variation?

Incentive Effects of Taxes on Income from 1/84 Capital: Alternative Policies in the 1980's Air Pollution and Lost Work $1 / 84$ 
1264 Pierre A. Mohnen, M. Ishaq Nadiri and Ingmar R. Prucha

1265 Olivier J. Blanchard

1266

Jacob A. Frenkel and Assaf Razin

1267 Patric H. Hendershott and David C. Ling

1268 Patric H. Henderahott

1269 Victor R. Fuchs
R\&D, Production Structure, and Productivity Growth in the U.S., Japanese and German Manufacturing Sectors

Current and Anticipated Deficits, Interest Rates and Economic Activity

Fiscal Policies, Debt, and International 1/84 Economic Interdependence

Trading and the Tax Shelter Value of Depreciable Real Estate

Expectations, Surprises and Treasury Bill Rates: 1960-82

$1 / 84$

"Though Much is Taken" -- Reflections on $1 / 84$ Aging, Health, and Medical Care

Note: Copies of the above working papers can be obtained by sending $\$ 1.50$ per copy to Working Papers, NBER, 1050 Massachusetts Avenue, Cambridge, MA 02138. Advance payment is required on orders totaling less than $\$ 10.00$. Please make check payable to National Bureau of Economic Research, Inc. 